\title{
RANCANG BANGUN PERANGKAT KEAMANAN BERBASIS INFRA MERAH PADA KANTOR PEGADAIAN PALOPO
}

\author{
Oleh: Irma \\ Program Studi Pendidikan Matematika Fakultas Tarbiyah STAIN Palopo \\ e-mail: irmailkom@yahoo.com
}

\begin{abstract}
Abstrak:
Artikel ini mencoba untuk mengembangkan sistem guna membantu masyarakat meningkatkan keamanan dengan bantuan sistem komputer. Penulis menerapkan sistem keamanan dari tindak pencurian dengan bantuan sensor dan perangkat mikrokontroler. Sistem kerjanya pun sederhana,yaitu mendeteksi pergerakan dari tubuh manusia menggunakan sinar infra merah, dengan meletakkan sensor pada tempat-tempat tertentu, maka sensor akan secara otomatis mendeteksi pergerakan dari seseorang. Mikrokontroler dapat di program untuk membunyikan alarm, menyalakan lampu, dan melaporkan tempat yang terdeteksi. Sensor menggunakan jenis Passive Infra Red dan bekerja dengan metode PyroElectric Signal sehingga hanya dapat membaca pergerakan makhluk hidup yang mengeluarkan suhu tubuh. Mikrokontroler yang digunakan buatan Atmel dan di program dengan bahasa C. Perangkat lunak sistem informasi pada komputer dibangun dengan pemrograman visual basic.
\end{abstract}

Kata Kunci: Mikrokontoler, Passive Infra Red.

\section{Latar Belakang}

Teknik-teknik manual kini dijadikan hal yang mudah dan otomatis, sumber tenaga manusia kini mulai tergantikan oleh tenaga sistem mekanik yang tidak kenal lelah dan bisa digunakan kapan saja. Semakin banyak keahlian yang dimiliki oleh manusia kini dapat dimasukkan ke dalam kecerdasan sebuah robot sehingga semakin banyak pula keahlian manusia yang kini tergantikan oleh keahlian robot di dalam dunia kerja. Sistem - sistem otamatis ini sebenarnya hanyalah sebuah pelengkap dan membantu manusia dalam melakukan pekerjaan. Setiap sistem canggih selalu ada seseorang yang harus bertanggung jawab dalam mengawasinya dan menentukan apakah sistem tersebut dapat terus diandalkan atau haruskah digantikan dengan sistem baru yang lebih baik.

Faktor keamanan adalah salah satu pertimbangan dalam menciptakan sebuah sistem yang baik. Sebaik-baiknya sebuah sistem komputer, tidak akan lengkap jika memiliki fasilitas keamanan yang memadai. Tanpa keamanan yang mumpuni, sebuah teknologi tidak akan dapat berkembang dan diterima di dalam masyarakat.

Salah satu kejahatan yang paling sering terjadi ialah pencurian, dan motifnya pun bermacam-macam. Mulai dari faktor 
ekonomi hingga faktor ingin mencapai sesuatu dengan jalan yang salah. Pencurian memang tidak bisa dihilangkan dari muka bumi, pencegahan adalah jalan terbaik agar siapa pun merasa aman. Ada banyak cara untuk mengamankan diri dari tindak pencurian, salah satunya dengan memasang sistem pengamanan. Sistem pengamanan tersebut dapat diterapkan sendiri seperti kunci, dan sensor.

Di dalam penelitian ini, penulis ingin menerapkan sistem keamanan dari tindak pencurian dengan bantuan sensor dan perangkat mikrokontroler. Sistem kerjanya pun sederhana,yaitu mendeteksi pergerakan dari tubuh manusia menggunakan sinar infra merah, dengan meletakkan sensor pada tempat-tempat tertentu, maka sensor akan secara otomatis mendeteksi pergerakan dari seseorang. Walaupun sensor dapat mendeteksi pergerakan, namun hasilnya belum dapat dimengerti manusia, itu sebabnya perangkat mikrokontroler digunakan untuk menerjemaahkan hasil deteksi sensor. Mikrokontroler dapat di program untuk membunyikan alarm, menyalakan lampu, dan melaporkan tempat yang terdeteksi.

Bukan hanya itu yang dapat dilakukan oleh perangkat mikrokontroler, informasi dari sensor dan tindakan yang diambil oleh mikrokontroler akan terus dipantau melalui perangka komputer. Informasi tersebut dapat berupa rekaman video, suara, dan tindakan lainnya yang akan dirancang nantinya. Hal tersebut dapat di realisasikan dengan membangun perangkat lunak menggunakan bahasa visual basic yang bertujuan untuk menghubungkan pengguna dengan perangkat sensor. Dengan begitu pengguna dapat menerima informasi berupa data digital dari sensor yang dikirim menuju komputer petugas

\section{Tujuan}

Tujuan yang ingin dicapai di dalam penelitian ini, diantaranya ialah mengembangkan sistem untuk membantu masyarakat meningkatkan keamanan dengan bantuan sistem komputer

\section{Batasan Masalah}

Mengingat luasnya bidang yang mencakup sistem keamanan dan penggunaan mikrokontroler, maka penelitian dibatasi pada:

1. Sensor menggunakan jenis Passive Infra Red dan bekerja dengan metode PyroElectric Signal sehingga hanya dapat membaca pergerakan makhluk hidup yang mengeluarkan suhu tubuh. 
109 | al-Khwarizmi, Volume III, Edisi 1, Maret 2015, Hal. 107 - 122.

2. Mikrokontroler yang digunakan buatan Atmel dan di program dengan bahasa $\mathrm{C}$.

3. Perangkat lunak sistem informasi pada komputer dibangun dengan pemrograman visual basic.

\section{Tinjauan Pustaka}

\section{a. Konsep Dasar Perancangan}

Menurut Andi Kristanto (2008:61) Perancangan ialah fase dimana diperlukan suatu keahlian perancangan untuk elemen elemen komputer yang akan menggunakan sistem yaitu pemilihan peralatan dan program komputer untuk sistem yang baru. Dalam hal ini merupakan waktu di mana seorang pemrogram bahasa komputer menggunakan keahliannya dalam mendesain sebuah perangkat lunak yang dapat digunakan untuk menyelesaikan suatu masalah spesifik.

Ada banyak jenis perancangan, seperti perancangan logo yang sering dikenal dengan mendesain logo. Mendesain sebuah perangkat lunak juga tidak jauh berbeda dengan mendesain logo, meskipun perangkat lunak yang digunakan untuk merancang keduanya berbeda. Dibutuhkan pengalaman dan pemikiran yang bagus untuk merancang sebuah perangkat lunak yang baik, tidak hanya dalam hal tampilan yang mudah dimengerti, namun juga performa yang dimiliki perangkat lunak harus sesuai dengan harapan penggunanya.

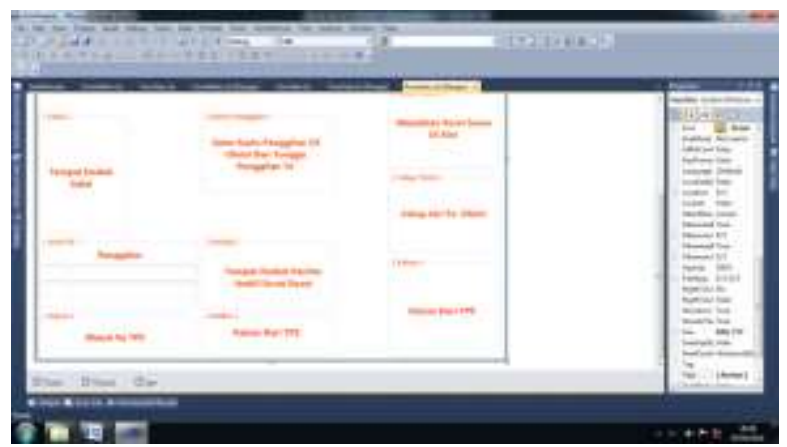

Gambar 1 Perancangan perangkat lunak (Sumber : msdn.microsoft.com)

Dalam banyak kasus, seringkali sebuah perangkat lunak sulit untuk digunakan oleh pengguna akibat dari antarmuka yang kurang baik, seperti tata letak yang tidak sesuai atau karena akibat yang lain. Perancangan sebuah perangkat lunak harus didahului dengan 
pengumpulan dan pemahaman data dari perangkat lunak yang akan dirancang dan dibangun oleh pemrogram perangkat lunak. Proses pengujian yang intensif akan menentukan apakah sebuah perangkat lunak telah dirancang dengan baik oleh pemrogram komputer.

\section{b. Konsep Dasar Infra Merah (IR)}

Menurut Andi Nalwan (2012:43) Led Inframerah adalah untuk memancarkan cahaya inframerah agar dapat diterima oleh komponen-komponen yang dapat merespon cahaya pada spektrum tersebut. Sinyal inframerah membutuhkan perangkat penerima inframerah yang disebut decoder. Sinyal yang dipancarkan oleh pemancar inframerah tidak dapat dilihat dengan mata, sebab spektrum warna dan gelombangnya tidak dapat ditangkap oleh retina mata.

Sinyal infra merah banyak digunakan pada perangkat yang berkomunikasi secara segaris dan memiliki jarak yang pendek. Contoh penggunaanya ialah remot tv, ac, dan mouse komputer.

\section{c. Konsep Dasar Mikrokontroler}

Menurut Iswanto (2008:2) mikrokontroler adalah suatu rangkaian terintegrasi (IC) yang bekerja untuk aplikasi pengendalian. Agar dapat bekerja dalam fungsi pengendaliannya, mikrokontroler memiliki central processing unit (CPU), random access memory (RAM), read only memory (ROM), unit penghitung, unit pewaktu dan unit keluaran dan masukan (I/O). CPU pada mikrokontroler merupakan otak dan mengolah semua perintah dan informasi yang menjadi masukan dan keluaran dari mikrokontroler. RAM adalah sebuah media penyimpanan sementara atau memori sementara untuk menyimpan data yang sedang diolah oleh CPU. ROM sendiri merupakan media penyimpanan yang hanya dapat dibaca oleh CPU, hal ini disebabkan ROM hanya dapat diisi melalui program dan alat yang dioperasikan melalui komputer. ROM menyimpan program yang dibuat oleh manusia untuk mengendalikan kerja dari sebuah mikrokontroler.

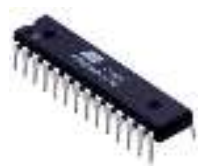

Gambar 2 mikrokontroler atmel (Sumber : lapantech.com)

Unit penghitung atau counter sering digunakan untuk mengolah perhitungan berupa perulangan yang menjadi masukan dan keluaran mikrokontroler. Unit pewaktu atau timer digunakan 
111 | al-Khwarizmi, Volume III, Edisi 1, Maret 2015, Hal. 107 - 122.

untuk mengendalikan operasi yang membutuhkan waktu tertentu menggunakan frekuensi tertentu, unit pewaktu dapat diprogram agar sesuai dengan kebutuhan dari pengendalian. Unit I/O merupakan terminal masukan dan keluaran dari mikrokontroler, masukan pada mikrokontroler umumnya sinyal tegangan dan arus yang bersifat analog dan masukan berupa sinyal data hanya dapat diterima oleh masukan digital. Begitupun dengan keluaran mikrokontroler, hanya dapat berupa sinyal analog dan digital yang harus diatur sedemikian rupa pada saat program dibuat.

Ada banyak jenis mikrokontroler di pasaran dengan dukungan program yang berbeda-beda, hal tersebut dikarenakan oleh arsitektur dari masing-masing mikrokontroler berbeda. Arsitektu mikrokontroler sendiri terbagi menjadi beberapa jenis, yaitu MCS51, AVR, ARM, PIC dan 8086. Arsitektur tersebut memiliki cara dan metode pemrograman yang berbeda, namun pada umunya semua mikrokontroler dapat diprogram menggunakan bahasa $\mathrm{C}$. Sehingga, di dalam penelitian ini bahasa $\mathrm{C}$ akan digunakan untuk memprogram mikrokontroler. Sebelum memprogram sebuah mikrokontroler, harus diketahui terlebih dahulu fungsi dari setiap pin yang ada pada mikrokontroler. Sebab, untuk dapat berkomunikasi, program yang dibuat harus sesuai dengan fungsinya. Sebagai contoh, jika ingin mengaktifkan pin nomor 2, perintah di dalam program bukan lagi nomor 2 melainkan alamat dari pin tersebut. Setiap mikrokontroler memiliki alamat dan penomoran tersendiri untuk tiap pin masukan dan keluarannya.

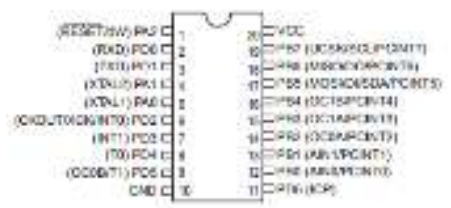

Gambar 3 pin atmel atmega 8 (Sumber : atmel.com)

Dari contoh mikrokontroler di atas, maka dapat dilihat bahwa sebuah pin dari mikrokontroler dapat memiliki fungsi lebih dari satu. Sehingga, perintah tertentu juga harus disisipkan sebelum menggunakan sebuah pin. Hal tersebut bertujuan agar sebuah pin digunakan dengan sebuah fungsi tertentu. Sehingga apa yang diharapkan, dapat tercapai. Namun tidak semua pin dapat diprogram dan digunakan, pin VCC misalnya, digunakan untuk memberi sumber daya berupa tegangan positif untuk menjalankan mikrokontroler. Pin GND untuk tegangan negatif, dan RESET untuk memulai ulang kerja dari mikrokontroler. Sehingga, 
ketelitian dalam membangun sebuah sistem berbasis mikrokontroler adalah sebuah keharusan yang mutlak dimiliki oleh pengguna.

\section{d. Konsep Dasar Sensor}

Menurut Gunarta (2011) sensor adalah jenis tranduser yang digunakan untuk mengubah ariasi mekanis, magnetis, panas, sinar dan kimia menjadi tegangan dan arus. Sensor seringkali digunakan untuk melakukan pengukuran, pendekteksian dan pengedalian sebuah sistem. Ada banyak macam sensor dan berbagai fungsi dari sensor tersebut dan dapat diimplementasikan secara bersamaan untuk mendukung sistem yang kompleks. Bentuk sensor dapat dilihat pada gambar 1 di bawah ini :

\section{Gambar 4 Sensor suhu LM35 (Sumber : National.com)}

Sensor - sensor dirancang memiliki karakteristik yang berbeda, dengan harga yang berbeda pula maka kebutuhan dari sensor tersebut dapat ditentukan berdasarkan rancangan sistem yang akan dibangun. Sensor - sensor juga dibedakan menjadi dua jenis berdasarkan jenis data yang dihasilkan, diantaranya :

1) Sensor digital. Sensor digital menggunakan komunikasi Serial dan $I 2 C$ atau Two Wire Interface (TWI). Sensor digital menghasilkan data dalam bentuk data digital heksadesimal dan harus diolah dengan metode tertentu berdasarkan pabrik pembuat sensor tersebut. Sensor digital menghasilkan data yang akurat, cepat, dan hemat daya maupun jalur masukan dan keluaran. Namun kelemahan dari sensor digital ialah proses pengolahan datanya yang sedikit rumit dan membutuhkan memori sistem yang lebih besar dari sensor analog. Belum lagi sensor digital memiliki batasan jarak dengan mikrokontroler yang akan mengolah datanya, jika terlalu jauh maka data yang dihasilkan akan rusak dan tidak dapat diolah.

2) Sensor analog. Sensor analog berkomunikasi dengan voltase, arus, dan resistansi. Data yang dihasilkan dari sensor analog lebih mudah untuk diolah dan membutukan memori yang cukup kecil. Sensor analog juga dapat digunakan lebih jauh dibandingkan dengan sensor digital, namun konsekuensi dari penggunaan sensor analog ialah penggunaan jalu komunikasi 
113 |al-Khwarizmi, Volume III, Edisi 1, Maret 2015, Hal. 107 - 122.

lebih banyak, data tidak seakurat digital, dan mengkonsumsi daya cukup besar.

\section{e. Alat Perancangan Sistem}

Menurut Sri Dharwiyanti (2012:2) Unified Modeling Language (UML) adalah sebuah bahasa yang telah menjadi standar dalam industri visualisasi, merancang dan mendokumentasikan sistem piranti lunak. UML dapat digunakan dalam pembuatan model untuk semua jenis aplikasi piranti lunak, dimana aplikasi tersebut dapat berjalan pada piranti keras, sistem operasi dan jaringan apapun, serta ditulis dalam bahasa pemrograman apapun. Model yang dimaksud adalah proses merancang piranti lunak sebelum melakukan pengkodean (coding). UML mempunyai konsep dasarclass dan operation yang digunakan untuk pemrograman software dengan menggunakan bahasa-bahasa pemrograman yang berorientasi objek.

UML meliputi simbol-simbol dan suatu tata bahasa yang menjelaskan bagaimana simbol-simbol tersebut dapat digunakan. Dengan UML merupakan bahasa pemodelan yang universal dimana digunakan sebagai sarana komunikasi dalam perancangan suatu software. Diagram UML yang paling sering digunakan untuk memodelkan aplikasi berorientasi objek terdiri dari 4 macam yakni :

Use Case Diagram

Tabel 1 Use case (Sumber : Sri Dharwiyanti (2011))

\begin{tabular}{|c|c|c|}
\hline Simbol & Nama & Keterangan \\
\hline & Aktor & $\begin{array}{l}\text { Menspesifikasikan himpunan peran Yang } \\
\text { penguna mainkan ketika berinteraksi } \\
\text { dengan use case }\end{array}$ \\
\hline & Dependency & $\begin{array}{l}\text { Hubungan dimana perubahan yang terjadi } \\
\text { pada suatu elemen mandiri akan } \\
\text { mempengaruhi elemen yang bergantung } \\
\text { padanya elemen yang tidak mandiri. }\end{array}$ \\
\hline I & Generalization & $\begin{array}{l}\text { Hubungan dimana objek anak berbagi } \\
\text { perilaku dan struktur data dari objek yang } \\
\text { ada diatasnya. }\end{array}$ \\
\hline & Extend & $\begin{array}{l}\text { Menspesifikasikan bahwa use case target } \\
\text { memperluas perilaku dari use case sumber } \\
\text { pada suatu titik yang diberikan. }\end{array}$ \\
\hline & System & $\begin{array}{l}\text { Menspesifikasikan paket yang } \\
\text { menampilkan sistem secara terbatas }\end{array}$ \\
\hline & Use Case & $\begin{array}{l}\text { Deksripsi dari urutan aksi-aksi yang } \\
\text { ditampilkan sistem yang menghasilkan } \\
\text { suatu hasil yang terukur bagi suatu faktor }\end{array}$ \\
\hline
\end{tabular}


115 | al-Khwarizmi, Volume III, Edisi 1, Maret 2015, Hal. 107 - 122.

\section{f. Kamus Data}

Menurut Jogiyanto H. (1989:725) kamus data adalah katalog fakta tentang data dan kebutuhan informasi dari suatu sistem informasi. Dengan menggunakan kamus data, analis sistem dapat mendefinisikan data yang mengalir di sistem dengan lengkap. Pada tahap perancangan, kamus data digunakan untuk merancang input, laporan basis data. Kamus data dibuat berdasarkan arus data yang ada pada flow diagram.

1) Nama arus data. Karena kamus data dibuat berdasarkan arus data yang mengalir dicatat dikamus data.

2) Bentuk data perlu dicatat dikamus data, kerena dapat digunakan untuk mengelompokkan data ke dalam kegunaanya sewaktu perancangan sistem.

3) Arus data menunjukkan dari mana data mengalir dan kemana data akan menuju. Keterangan arus data perlu dicatat di kamus data supaya memudahkan dalam pencarian arus data di UML.

4) Untuk memperjelas lagi tentang makna dari arus data yang dicatat di kamus data, maka bagian penjelasan dapat diisi dengan keterangan - keterangan arus data tersebut.

5) Periode menunjukkan kapan terjadinya arus data ini. Periode perlu dicatat di kamus data, karena dapat digunakan mengindentifikasikan kapan input data harus dimasukkan ke sistem, kapan harus dilakukan dan kapan laporan harus dihasilkan.

6) Struktur data menunjukkan arus data yang dicatat di kamus data yang terdiri dari item-item apa saja. Relasi Data atau biasa disebut relasi tebel adalah hubungan antara tabel yang satu dengan tabel yang lainnya yang dibuat untuk memudahkan proses manipulasi data (menambah, merubah, dan menghapus). Sehingga dalam proses manipulasi tidak terjadi anomali atau kerangkapan data.

\section{Perancangan Sistem}

\section{Class Diagram}

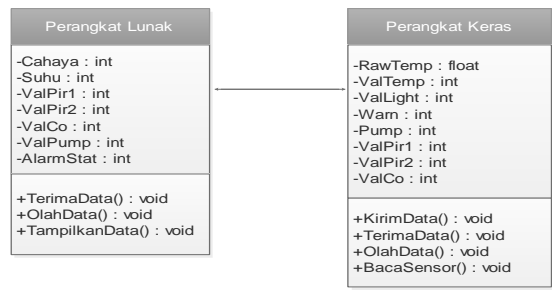

Gambar 5 Class diagram 


\section{$\underline{\text { Activity Diagram }}$}

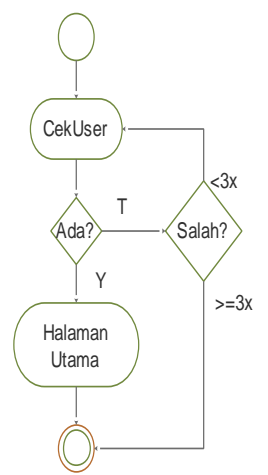

Gambar 6 activity diagram login

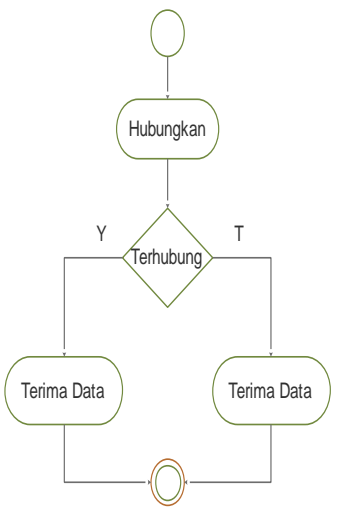

Gambar 7 activity diagram koneksi

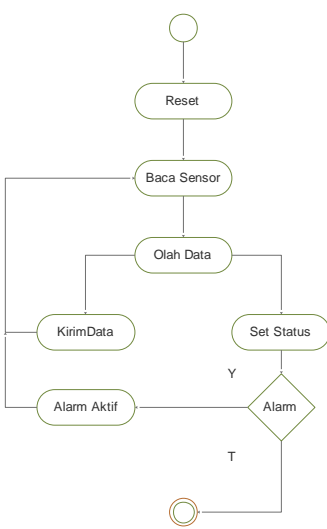

Gambar 8 activity diagram mikrokontroler

\section{Perancangan antarmuka}

a. Halaman masuk

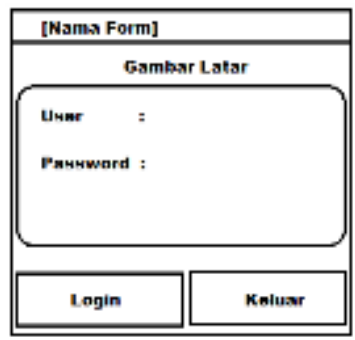

Gambar 9 perancangan halaman masuk

Keterangan :

1) [Nama Form] ialah nama halaman dari setiap form yang ditampilkan oleh aplikasi.

2) Gambar latar ialah gambar yang digunakan sebagai latar belakang form.

3) User \& Password ialah nama akun dan kata kunci saat akan menggunakan aplikasi.

4) Tombol Login untuk masuk ke sistem dan Keluar untuk menutup aplikasi.

b. Halaman Utama 
117 | al-Khwarizmi, Volume III, Edisi 1, Maret 2015, Hal. 107 - 122.

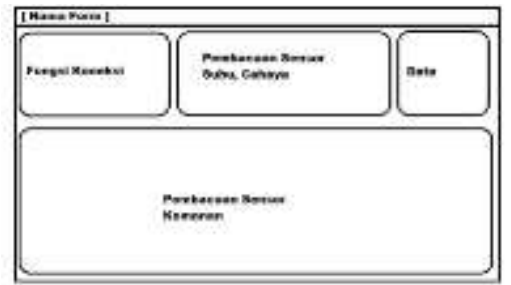

Gambar 10 perancangan halaman utama

Keterangan :

1) Pada bagian fungsi koneksi, fungsi yang dimasukkan ialah daftar port COM, kecepatan baud rate, tombol refresh untuk mengulangi pencarian port COM dan tombol konek untuk memulai koneksi dengan perangkat mikrokontroler.

2) Pada bagian pembacaan sensor suhu, cahaya terdapat fungsi untuk menampilkan hasil pembacaan dari sensor suhu dan cahaya pada mikrokontroler.

3) Bagian Data terdapat fungsi untuk membaca karakter yang diterima oleh aplikasi dari perangkat mikrokontroler.

4) Bagian pembacaan sensor keamanan berisi fungsi pembacaan dari perangkat sensor gerak, sensor asap, pompa, listrik dan alarm.

\section{Pengujian Sistem}

\section{Pengujian koneksi}

Pada pengujian koneksi, penulis menguji apakah aplikasi dapat terkoneksi dengan perangkat keras mikrokontroler.

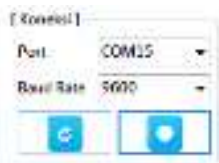

Gambar 11 fungsi koneksi

Kerangan : aplikasi dapat terkoneksi dengan port COM15 dengan baud rate 9600 tanpa ada peringatan kesalahan.

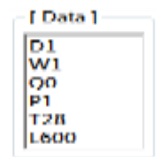

Gambar 12 fungsi peneriamaan data 
Keterangan : aplikasi dapat menerima karakter data yang dikirimkan oleh perangkat mikrokontroler. Data tersebut kemudia akan diterjemahkan menjadi hasil pembacaan oleh aplikasi.

2. Pengujian pembacaan sensor

Pada pengujian ini, penulis menguji fungsi pembacaan dari semua sensor yang terhubung dengan mikrokontroler.

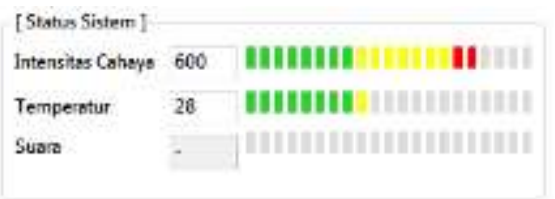

Gambar 13 pembacaan sensor suhu \& cahaya

Keterangan : aplikasi dapat menampilkan intensitas cahaya yang ditangkap oleh sensor cahaya. Aplikasi juga dapat menampilkan informasi dari suhu ruangan yang diterima oleh sensor suhu.

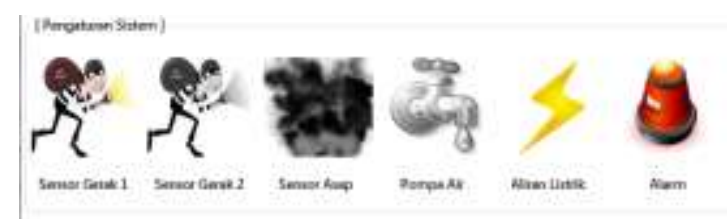

Gambar 14 pembacaan sensor keamanan

Keterangan : aplikasi dapat membaca status dari setiap sensor keamanan yang terhubung dengan mikrokontroler. Sensor-sensor tersebut hanya mengirimkan data berupa status aktif atau tidak dengan nilai 1 dan 0 .

3. Pengujian sensor

a. Sensor gerak 1

Pada pengujian ini, penulis menguji respon dari sensor PIR yang pertama dan dapat dilihat pada gambar di bawah, saat penulis meletakkan tangan di depan sensor PIR, alarm berbunyi dan informasi dari aplikasi pada komputer menunjukkan sensor gerak 1 aktif.

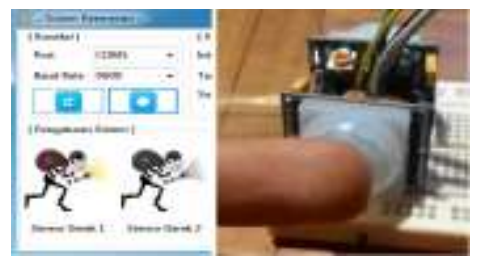

Gambar 15 pengujian PIR 1 
119 | al-Khwarizmi, Volume III, Edisi 1, Maret 2015, Hal. 107 - 122.

b. Sensor gerak 2

Sama seperti pada pengujian sensor gerak yang pertama, pada saat penulis berjalan atau meletakkan tangan di depan sensor PIR, maka alarm berbunyi dan aplikasi keamanan menunujukkan adanya gerakan yang tebaca oleh sensor PIR yang kedua seperti pada gambar di bawah ini.

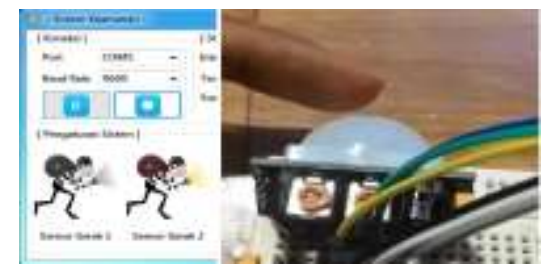

Gambar 16 pengujian PIR 2

c. Pengujian sensor asap

Pada pengujian sensor asap, penulis menggunakan asap dari kertas yang dibakar lalu didekatkan dengan sensor asap. Respon dari sensor segera memberikan informasi pada aplikasi dan mengindikasikan bahwa terdapat asap. Karena mikrokontroler telah diprogram untuk memutuskan aliran listrik dan mengaktifkan pompa saat terdapat asap, maka aplikasi keamanan menginformasikan bahwa pompa aktif dan listrik dipadamkan seperti pada gambar di bawah.

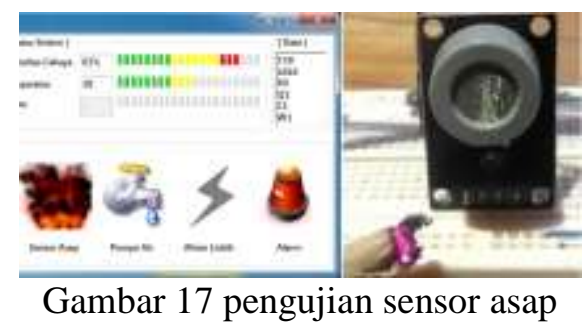

d. Pengujian sensor suhu

Pada pengujian sensor suhu, penulis mendekatkan objek yang berupa bara anti nyamuk bakar. Hal tersebut mengakibatkan sensor suhu menjadi panas dan memberikan informasi suhu yang meningkat pada aplikasi keamanan pada komputer. 


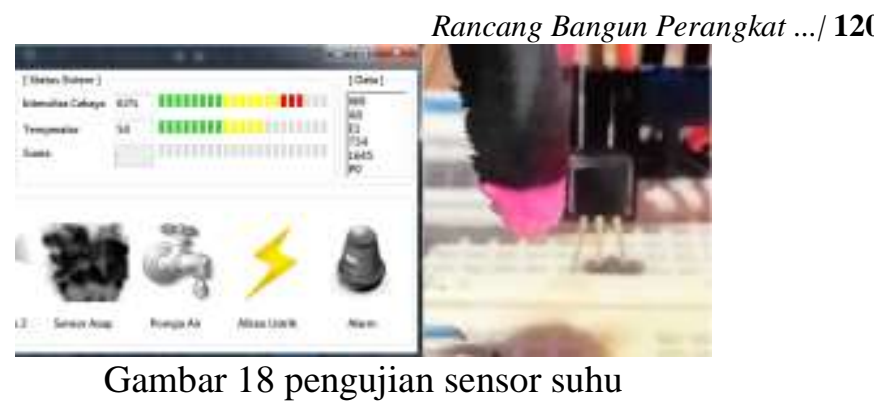

e. Pengujian sensor cahaya

Pada pengujian ini, penulis menutupi sensor LDR dengan bayangan, sehingga area disekitar sensor menjadi gelap. Respon dari sensor segera ditampilkan oleh aplikasi pada komputer, yaitu menurunnya persentase intensitas cahaya.

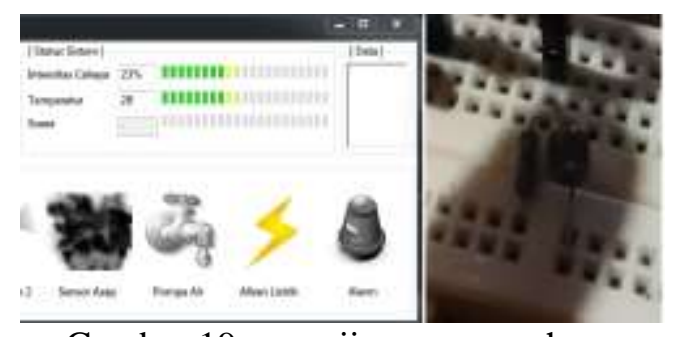

Gambar 19 pengujian sensor cahaya

f. Pengujian alarm

Pada pengujian ini, alarm berbunyi saat ada keadaan darurat yang dilaporkan oleh mikrokontroler dan ditampilkan oleh aplikasi pada komputer.

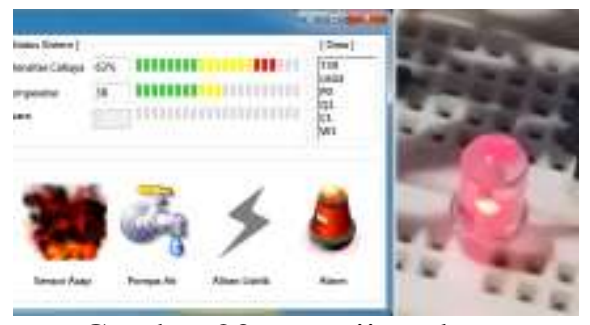

Gambar 20 pengujian alarm

\section{Penutup}

1. Kesimpulan

Sebagai kesimpulan dalam penelitian ini, ada beberapa yang telah dapatkan. Yang peratama ialah sistem yang telah dibangun dan diimplementasikan oleh penulis untuk mencegah adanya 
121 | al-Khwarizmi, Volume III, Edisi 1, Maret 2015, Hal. 107 - 122.

tindak kriminal telah bekerja, meskipun tidak dapat dikatakan bekerja $100 \%$ sesuai dengan harapan penulis. Hal ini disebabkan oleh kekurangan dari penulis maupun kemampuan dari alat yang terbatas. Nanum, meski pun kemampuan dari perangkat yang dibangun oleh penulis terbatas, akan tetapi fungsi utamanya dapat berkerja sesuai dengan yang telah direncanakan.

Yang kedua ialah fungsi sensor yang dipasangkan dengan perangkat mikrokontroler dapat bekerja dengan baik. Meskipun sensor-sensor yang digunakan merupakan bentuk sederhana dari sensor-sensor yang digunakan pada perangkat sejenis dalam kategori keamanan. Baik sensor asap, sensor cahaya dan sensor suhu, merupakan sensor sederhana dan mudah untuk diaplikasikan diberbagai macam jenis penggunaan. Meskipun sifatnya hanya sebagai pelengkap perangkat keamanan yang disandingkan dengan sensor deteksi, namun keberadaan dari sensor-sensor tersebut sangatlah membantu.

Hal yang ketiga adalah mudahnya merancangan aplikasi dengan menggunakan perangkat mikrokontroler. Ada banyak dokumentasi yang dapat penulis gunakan sebagai referensi dalam membangun aplikasi menggunakan mikrokontroler. Bukan hanya itu, mudahnya mendapatkan perangkat mikrokontroler yang sesuai dengan kebutuhan ditambah dengan banyak modul-modul yang tersedia yang dapat digunakan. Semua hal itu menjadikan kegiatan perangcangan dan pembangunan perangkat keamanan berbasis mikrokontroler semakin mudah

\section{Saran}

Ada banyak hal yang dapat dikembangkan melalui teknik robotika dan elektronika, tidak hanya sistem keamanan yang dibangun oleh penulis. Oleh sebab itu, ke depannya penulis berharap di kota Palopo, terutama di lingkungan Fakulta Teknik Komputer dapat menjadikan teknik robotika sebagia salah satu mata kuliah yang dapat diambil oleh mahasiswa untuk belajar lebih jauh mengenai robotika dan elektronika. 


\section{DAFTAR PUSTAKA}

Dharwiyanti, S. 2011. Pengenalan UML (online). http://ilmukomputer.com/yanti_uml.doc. Diakses pada 1 Oktober 2014.

Eko Kristanto, D. 2008. Rancang Bangun Sistem Keamanan Rumah Menggunakan Sensor Passive Infra Red KC7783R dan LM35 Berbasis Mikrokontroler AT89S51 (online). http://eprints.undip.ac.id . Diakses 3 Nopember 2014.

Gunarta, L. 2011. Jurnal Sensor dan Tranduser (Online). http://skp.unair.ac.id. Diakses 2 Nopember 2014.

Hartanto, D. 2005. Visual Downloader Untuk Microcontroller AT89C2051. Penerbit Andi, Yogyakarta.

Hartono, J. 1999. Pengenalan Komputer. Penerbit Andi, Yogyakarta.

Hartono, J. 1989. Analisis dan Desain Sistem. Penerbit Andi, Yogyakarta.

Iswanto. 2008. Belajar Mikrokontroler AT89S51 dengan Bahasa C. Penerbit Andi, Yogyakarta.

KBBI. 2014. Kamus Besar Bahasa Indonesia (online). http://kbbi.co.id/maling. Diakses pada 4 November 2014.

Kristanto, A. 2008. Perancangan Sistem Informasi dan Aplikasinya. Gava Media, Yogyakarta.

Nalwan, A. 2012. Teknik Rancang Bangun Robot. Penerbit Andi, Yogyakarta.

Rofik Mulyarto, A. 2008. Rekayasa Perangkat Lunak . Jilid 2. CV. Arya Duta, Depok. 